\title{
The effect of gamma rays irradiation on diversity of Musa paradisiaca var. sapientum as revealed by ISSR molecular marker
}

\author{
MARIA SERVIANA DUE ${ }^{1}$, ARI SUSILOWATI ${ }^{2}$, AHMAD YUNUS ${ }^{3, \bullet}$ \\ ${ }^{1}$ Bioscience Graduate Program, Graduate School, Universitas Sebelas Maret. Jl. Ir. Sutami 36 A, Surakarta 57126, Central Java, Indonesia. \\ ${ }^{2}$ Department of Biology, Faculty of Mathematics and Natural Science, Universitas Sebelas Maret. Jl. Ir. Sutami 36 A, Surakarta 57126, Central Java, \\ Indonesia \\ ${ }^{3}$ Department of Agrotechnology, Faculty of Agriculture, Universitas Sebelas Maret. Jl. Ir. Sutami 36 A, Surakarta 57126, Central Java, Indonesia. \\ Tel./fax.:+62-271-637457, •email: yunusuns17@gmail.com, mariaserviana93@gmail.com
}

Manuscript received: 7 February 2019. Revision accepted: 28 April 2019.

\begin{abstract}
Due MS, Susilowati A, Yunus A. 2019. The effect of gamma rays irradiation on diversity of Musa paradisiaca var. sapientum as revealed by ISSR molecular marker. Biodiversitas 20: 1416-1422. Pisang Ambon (Musa paradisiaca var. sapientum (L.) Kunt.) is one of the horticultural commodities that have high production in Indonesia, making it a superior product. Bananas are propagated vegetatively, which hampers the production of genetic variation and requires a long generation time in the vegetative cycle. This study aimed to determine the diversity of Pisang Ambon induced by gamma radiation of various dosages (10 Gy, 20 Gy and 30 Gy) in vitro based on the ISSR (Inter-Simple Sequence Repeats) marker. The results showed that gamma-ray radiation influenced the morphological properties of plant height, stem diameter, leaf length, leaf width and leaf number based on ANOVA variance analysis. Increased growth occurs in plants with radiation doses of $10 \mathrm{~Gy}$ and $20 \mathrm{~Gy}$. The molecular analysis of ISSR uses 6 primers, namely ISSR 835, ISSR 836, ISSR 846, ISSR 847, ISSR 848 and ISSR 855. Of the 6 primers, only 2 primers were able to produce polymorphisms above 50\%. A total of 9 bands were produced, in which 8 bands showed polymorphic with a percentage of $90 \%$. The similarity matrix ranged from 0.25-0.93, indicating the level of variation between mutants. The result of dendrogram was divided into two groups with a coefficient distance of 0.47-0.93; plants at a dose of 10 Gy have the highest diversity with the furthest coefficient of diversity distance of 0.47 .
\end{abstract}

Keywords: Diversity, gamma ray, irradiation, molecular markers, pisang ambon

\section{INTRODUCTION}

Banana (Musa spp.) is an important genus in the family of Musaceae which can be found on the African and Asian continents. Bananas are known to originate from South and Southeast Asia (Abdulhafiz et al. 2018). According to Crouch et al. (1998), bananas are the most widely cultivated fruit trees in tropical areas. Generally, banana plants have herbal habitus and only bear fruit once (monocarpic) and then die. Banana plants ranked fourth as the most important food crop in the world after rice, wheat and corn (Frison et al. 2004; Megia 2005).

Pisang Ambon (Musa paradisiaca var. sapientum (L.) Kunt.) is a tropical fruit that grows and has become popular in Indonesian. This banana species is a superior commodity, which contributes the most to national fruit production. This plant is popular because it tastes good, contains various nutrients, vitamins, and calories that are beneficial to health (Prahardini et al. 2011). Bananas are known as annual plants with their fruiting times which are not dependent on the season (Bakry et al. 2006).

Pisang Ambon is propagated vegetatively so that they have limitations in obtaining genetic variation and require a long generation time in the vegetative cycle. To obtain new superior varieties, improvements can be made to the nature of plants by increasing their genetic diversity. According to Sari et al. (2014), an increase in genetic diversity of a plant can be done through genetic introduction, hybridization, induced mutation, and genetic engineering. Among these methods, induced mutation combined with in vitro culture techniques is an optimistic and faster way in an effort to increase plant genetic diversity.

Induced mutation with in vitro culture techniques has been widely used for various purposes such as improving plants through increasing genetic diversity and selecting mutants as potential sources to produce a new cultivar (Orbovic et al. 2008). According to Javed et al. (2004), in vitro mutation breeding can overcome the problems that occur when producing superior new banana cultivars for the sustainability of fruit production without the spread of disease. With the discovery of this technology, a large number of mutant varieties have been developed for commercial cultivation (Pena et al. 2012).

Induced mutation in plants can be done using mutagens, either physical or chemical mutagens. The use of physical mutagens in plants is highly recommended as compared to chemical mutagens since the physical mutagens are more environmentally friendly and have a high frequency of mutations. Among existing physical mutagens, gamma rays are the most commonly used as mutagen agents in in-vitro induction of mutation experiments (Roux et al. 2004). The gamma rays are selected as a mutagenic agent because it has a higher level of accuracy, a strong absorption power to plant's biological material and is able to ionize the molecules it passes (Harten 1998). Kovac and Keresztes (2002) explained that the biological effects of gamma 
radiation are very dependent on the interaction of atoms or molecules in cells, especially in water to produce free radicals.

Previous studies on induced mutation using gamma rays with in vitro culture techniques produced positive results where gamma-ray mutagens provided advantages such as the occurrence of physiological and morphological modifications in mutated plant material. Even so, the optimum dose of the radiation agent must still be elucidated. A previous study conducted by Dwimahayani and Widiarsih (2011) showed a change in Chrysanthemum plants at a dose of 10 Gy carried out in vitro. The gammaray radiation dose of $10 \mathrm{~Gy}$ increased the height of Cavendish banana shoots, but the high irradiation dose will give more inhabitance on its growth (Qamar et al. 2016). In addition, Abdulhafiz et al. (2018) showed that radiation doses of $10 \mathrm{~Gy}$ and 20 Gy had a significant effect on quantitative and qualitative morphology of pisang tanduk.

Gamma rays radiation which applied to plants will affect the morphological characteristics due to damage to DNA. This damage induces mutations at both the chromosome level and free radical genes. Molecular techniques such as molecular marker offers an opportunity to help detect the changes by examining both genetic variants in the population and detect the desired mutants in a more robust way (Abdulhafiz et al. 2018). This molecular marker can serve as complements for morphological markers. Molecular markers can reveal differences among irradiated and non-irradiated individual plants at the DNA level and, thus, provide a more direct, reliable and efficient tool for germplasm conservation and management (Kumar et al. 2006).

One of the molecular markers used to detect genetic diversity is Inter-Simple Sequence Repeats (ISSR). ISSR is a part of microsatellite that does not encode protein (noncoding region), and it is usually mono, di or trinucleotide ( $\mathrm{Ng}$ and Tan 2015). Generally, ISSR markers are more sensitive in detecting genetic diversity at low levels, easier and cheaper than other markers such as RAPD. ISSR markers have been widely used, including analysis of the diversity of mangosteen (Widiastuti et al. 2013), genetic polymorphism from coconut crossing (Manimekalai et al. 2003), detection of DNA polymorphism in Curcuma alismatifolia (Taheri et al. 2013), and for genetic linkages in plants Catharanthus roseus (Gupta et al. 2007). The purpose of this study was to use ISSR molecular markers to reveal the genetic diversity of pisang ambon caused by in vitro gamma-ray irradiation.

\section{MATERIALS AND METHODS}

\section{Plant material}

The plant materials in this study were the aseptic shoots of pisang ambon that were in one-month-old multiplication stage obtained from the Salaman Horticulture Seed Garden, Magelang, Central Java, Indonesia.

\section{Gamma irradiation}

The aseptic shoot plantlets of pisang Ambon were first proliferated on Murashige and Skoog (MS) media in culture bottles and were labeled according to the treatment. Furthermore, the culture bottles were inserted into the Cobalt $^{60}$ gamma chamber for the radiation process with radiation doses of $0 \mathrm{~Gy}, 10 \mathrm{~Gy}, 20 \mathrm{~Gy}$, and $30 \mathrm{~Gy}$. Irradiation of plant materials was carried out at the Research and Development Center for Isotope and Radiation Technology, the National Nuclear Energy Agency (BATAN) Pasar Jumat, South Jakarta, Indonesia.

\section{Subculture of plantlet}

The shoots of the banana from the gamma rays irradiation are removed from the old medium, then subcultured to the new medium twice at intervals of 4 weeks in liquid medium containing MS, growth regulators NAA and sucrose. After 8 weeks of age, the buds were transferred and cultured on MS solid media, with the addition of NAA and sucrose, for 4 weeks to induce shoot lengthening and further root formation. Furthermore, the plantlets were ready to be transferred to the planting media.

\section{Greenhouse transfer and morphological analysis}

Rooted shoots were washed in running tap water and acclimatized in hydroponic media for 4 weeks with routine provision of nutrition in every 2 days. After 4 weeks, the plants were moved and planted in polybags containing a mixture of soil, manure and fuel husk of the same ratio. Polybags containing plants are treated with regular weeding and watering every morning and evening using water in the glasshouse of the Faculty of Agriculture, Sebelas Maret University. Morphological observations were carried out on vegetative characteristics such as plant height, stem diameter, leaf length, leaf width and number of leaves per plant.

\section{ISSR Assay}

Plant material for extraction. Fresh leaf samples were taken from banana plants which were previously used for quantitative morphological characterization observations. The leaves were young leaves randomly selected from each treatment based on morphological characteristics which showed the most noticeable differences compared to controls.

Preparation of DNA template. Leaf samples were extracted using DNA Mini Kit (Plant) provided by Geneaid. The quality and quantity of extracted DNA were examined using a standard biophotometer and electrophoresis.

DNA amplification. Amplification was done by PCR (Polymerase Chain Reaction) reaction using a Thermal cycler (Eppendorf Thermal cycler) device. The amplification process used 6 ISSR primers (Table 1). The PCR reaction was carried out at a total volume of $50 \mu \mathrm{L}$ for each PCR tube using MyTaq TM HS Red Mix (Bioline). The PCR reaction consisted of $1 \mu \mathrm{L}$ DNA template, $1 \mu \mathrm{L}$ primer, $25 \mu \mathrm{L}$ MyTaq HS Red Mix and $23 \mu \mathrm{L}$ water $\left(\mathrm{ddH}_{2} \mathrm{O}\right)$. PCR was carried out at an initial denaturation of $95^{\circ} \mathrm{C}$ for 3 minutes, followed by 35 cycles of denaturation at $95^{\circ} \mathrm{C}$ for 15 seconds, annealing at $50^{\circ} \mathrm{C}$ for 15 seconds, extension at $72^{\circ} \mathrm{C}$ for 10 seconds and final extension for 10 minutes at $72^{\circ} \mathrm{C}$. The PCR results were detected in 
electrophoresis using $1 \%$ agarose which was made by dissolving 0.5 grams of agarose into $50 \mathrm{ml}$ of $1 \mathrm{X}$ TAE buffer. The running process was carried out with an electric current of 85 volts for 45 minutes. Running gel was soaked in EtBR (ethidium bromide) for 15 minutes and rinsed using distilled water. The results of electrophoresis were visualized by using UV light using a Biodoc Analyze and photographed using Olympus digital camera. The size of the amplification product was estimated based on $100 \mathrm{bp}$ DNA ladder (Geneaid).

\section{Data analysis}

Quantitative morphological characters were analyzed by analysis of variance (ANOVA) on the level $5 \%$. If the treatment has real effects, the test will be continued by Duncan's Multiple Range Test (DMRT) on the level of 5\%. Analysis of molecular data was done by looking at the results of the advent of DNA amplification using a primer. The obtained data in scoring was present (1) or not present (0) ribbon of each individual at a certain size in each primer. From these data, it can be seen the number and percentage of polymorphic loci. Next, cluster analysis (Cluster analysis) used the NTSYS (Numerical Taxonomy and Multivariate Analysis System) program version 16 with the method of Group Unity Pair Arithmetic Method (UPGMA) SIMQUAL (similarity qualitative) function. The genetic similarity matrix was calculated based on the DICE coefficient.

\section{RESULTS AND DISCUSSION}

\section{Effect of gamma irradiation on morphological characters}

In this study, the number of explants living after the advanced root extension stage in vitro that is ready for acclimatization is 28 experimental plants with 7 of them being controls. This plant does not experience death until the end of quantitative vegetative observation (15 MST). However, there are some plants that experience stunting characterized by a decrease in the process of growth and development. The declining process of growth and development of pisang Ambon kuning is caused by exposure to gamma radiation which produces ions and free radicals causing changes in the levels of genomes, chromosomes, and DNA (Herison et al. 2008).

ANOVA results showed that gamma irradiation affected the quantitative morphological traits of pisang ambon such as plant height, stem diameter, leaf length, leaf width and number of leaves.
Based on data (Table 2), it can be seen that plants treated with a radiation dose of $10 \mathrm{~Gy}$ have the highest average plant height of $22.69 \mathrm{~cm}$ or increased by $13.88 \%$ when compared to the control treatment $(0 \mathrm{~Gy})$. For plants at radiation doses of $20 \mathrm{~Gy}$ and $30 \mathrm{~Gy}$, they are reduced by $4.24 \%$ and $15.04 \%$ respectively. However, plant height does not show a significant difference between control and radiation-treated plants. Observations on the quantitative character of stem diameter show a significant difference $(<$ 0.05 ) between the control and irradiated plants. The stem diameter ranges from $4.52 \mathrm{~mm}$ to $7,13 \mathrm{~mm}$. The radiation dose of $10 \mathrm{~Gy}$ is the dose with the largest stem diameter acquisition of $7.13 \mathrm{~mm}$ and the lowest is in irradiated plants at a dose of 30 Gy with $4.52 \mathrm{~mm}$ (reduced by $23.12 \%$ ). The treatment on plant with $20 \mathrm{~Gy}$ results in average stem diameter of $6.91 \mathrm{~mm}$ or an increase in growth of $17.51 \%$ compared to the control which has an average of $5.88 \mathrm{~mm}$. The diameter of the plant stem from the treatment of gamma-ray irradiation $10 \mathrm{~Gy}$ is not significantly different from each other.

The leaves of pisang ambon differ significantly between control plants with irradiation treatment plants of $20 \mathrm{~Gy}$ and $30 \mathrm{~Gy}$, while in the $10 \mathrm{~Gy}$ treatment, it does not differ significantly. The treatment of $20 \mathrm{~Gy}$ irradiation has the highest leaf length of $12.69 \mathrm{~cm}$ or increased by $8.92 \%$ compared to the control, whereas the treatment of $30 \mathrm{~Gy}$ is the treatment with the smallest leaf length acquisition of $9.06 \mathrm{~cm}$ (reduced by $22.23 \%$ ).

Gamma-ray irradiation does not have a significant effect on the control and the treated plant on leaf width and number of leaflets. The highest leaf width of $5.15 \mathrm{~cm}$ and the highest number of leaflets at 5.61 occurred in the treatment of $10 \mathrm{~Gy}$, while the lowest leaf width $(3.56 \mathrm{~cm})$ and the number of leaflets (4.61) are observed in the treatment of $30 \mathrm{~Gy}$. Plant height, leaf width and number of leaves of pisang ambon plant decreased at the highest irradiation dose (30 Gy), although it does not reach a significant level.

Table 1. List of primers Inter-Simple Sequence Repeat (ISSR) (Tantasawat et al. 2010)

\begin{tabular}{lll}
\hline Primers & Sequence & $\begin{array}{l}\text { Tm } \\
\left({ }^{\circ} \mathbf{C}\right)\end{array}$ \\
\hline ISSR 835 & 5'-AGA GAG AGA GAG AGA GYC-3' & 48.9 \\
ISSR 836 & 5'-AGA GAG AGA GAG AGA GYA-3' & 48.5 \\
ISSR 846 & 5'-GAG AGA GAG AGA GAG AA-3' & 45.7 \\
ISSR 847 & 5'-CAC ACA CAC ACA CAC ARC-3' & 53.1 \\
ISSR 848 & 5'-CAC ACA CAC ACA CAC ARG-3' & 52.7 \\
ISSR 855 & 5'-ACA CAC ACA CAC ACA CYT-3' & 53.1 \\
\hline
\end{tabular}

Table 2. The effect of gamma-ray irradiation on the quantitative morphological properties of pisang ambon

\begin{tabular}{|c|c|c|c|c|c|}
\hline \multirow{2}{*}{$\begin{array}{l}\text { Dose } \\
(G y)\end{array}$} & \multicolumn{5}{|c|}{ Observation parameters of growth } \\
\hline & Plant height $(\mathrm{cm})$ & Stem diameter $(\mathrm{mm})$ & Leaf length $(\mathrm{cm})$ & Leaf width (cm) & Number of leaves \\
\hline $0 \mathrm{~Gy}$ & $19.81 \pm 6.79^{a}$ & $5.88 \pm 1.53^{\mathrm{ab}}$ & $11.65 \pm 2.92^{\mathrm{ab}}$ & $5.04 \pm 1.86^{\mathrm{a}}$ & $5.57 \pm 2.30^{\mathrm{a}}$ \\
\hline $10 \mathrm{~Gy}$ & $22.56 \pm 8.45^{\mathrm{a}}$ & $7.13 \pm 1.84^{\mathrm{b}}$ & $11.72 \pm 2.72^{\mathrm{ab}}$ & $5.15 \pm 1.85^{\mathrm{a}}$ & $5.61 \pm 2.37^{\mathrm{a}}$ \\
\hline $20 \mathrm{~Gy}$ & $18.97 \pm 6.44^{\mathrm{a}}$ & $6.91 \pm 1.44^{\mathrm{b}}$ & $12.69 \pm 3.25^{\mathrm{b}}$ & $5.07 \pm 1.67^{\mathrm{a}}$ & $5.46 \pm 2.16^{\mathrm{a}}$ \\
\hline $30 \mathrm{~Gy}$ & $16.83 \pm 6.23^{\mathrm{a}}$ & $4.52 \pm 1.00^{\mathrm{a}}$ & $9.06 \pm 2.59^{\mathrm{a}}$ & $3.56 \pm 1.42^{\mathrm{a}}$ & $4.61 \pm 1.71^{\mathrm{a}}$ \\
\hline
\end{tabular}

Note: The number followed by the same letter within a column are not significantly different at $\mathrm{P}<0.05$ of DMRT test. 
Table 2. Number of amplified amplification product with two ISSR primers

\begin{tabular}{lccccc}
\hline \multicolumn{1}{c}{ Primers } & $\begin{array}{c}\text { Product } \\
\text { size (bp) }\end{array}$ & TAP & NMM & NPB & $\begin{array}{c}\text { PPB } \\
(\boldsymbol{\%})\end{array}$ \\
\hline ISSR 846 & $320-658$ & 5 & 1 & 4 & 80 \\
ISSR 855 & $275-1250$ & 4 & 0 & 4 & 100 \\
Total & & 9 & 1 & 8 & 180 \\
Mean & & 4.5 & 0.5 & 4 & 90 \\
\hline Note: TAP: & total amplified product; NMB: number of \\
monomorphic bands; NPB: number of polymorphic bands; PPB: \\
percentage of polymorphic bands.
\end{tabular}

Table 3. Similarity coefficient value of pisang ambon based on ISSR markers

\begin{tabular}{lcccc}
\hline & Control & $\mathbf{1 0}$ Gy & $\mathbf{2 0 ~ G y}$ & $\mathbf{3 0} \mathbf{~ G y}$ \\
\hline Control & 1.00 & & & \\
$\mathbf{1 0} \mathbf{~ G y}$ & 0.25 & 1.00 & & \\
$\mathbf{2 0 ~ G y}$ & 0.66 & 0.60 & 1.00 & \\
$\mathbf{3 0} \mathbf{~ G y}$ & 0.61 & 0.54 & 0.93 & 1.00 \\
\hline
\end{tabular}

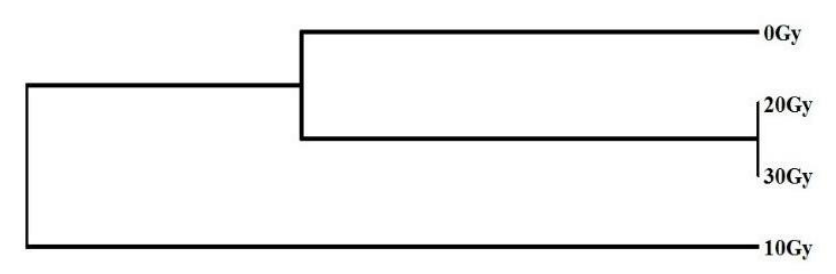

\begin{tabular}{|c|c|c|}
\hline 0.58 & & 0. \\
\hline
\end{tabular}

Figure 1. Dendrogram of ambon kuning based on ISSR markers

\section{Molecular marker analysis of ISSR}

DNA observation is carried out on 4 samples of pisang ambon kuning plants. Each sample is selected from each treatment (control, $10 \mathrm{~Gy}, 20 \mathrm{~Gy}, 30 \mathrm{~Gy}$ ) based on quantitative morphological observations that show better growth than other plants. From 6 primers only 2 primers meet the requirements or produced polymorphic bands above 50\%. The selected primer is the ISSR 846 primer with a polymorphic percentage of $80 \%$ and an ISSR 855 primer of $100 \%$.

Amplification of two primer results of the selection produced the amount of DNA bands in each of primer of 4 and 5 bands. The highest banding pattern was obtained from ISSR 846 primer with 5 bands, of which 4 bands were polymorphic and 1 monomorphic ribbon with sizes ranging from 320-658 bp. ISSR primer 855 produced 3 polymorphic banding patterns. This primer has a size between 275-1250 bp.

The similarity coefficient values obtained in the ISSR analysis (Table 3 ) ranges from 0.25 (between control plants and $10 \mathrm{~Gy}$ treatments) to 0.93 (between treatments of 30 Gy and $20 \mathrm{~Gy}$ ). The coefficient value approaching 0 indicates far similarity while the coefficient value which is farther away from 0 and close to 1 shows close similarity.

Dendrogram diversity analysis (Figure 1) shows similarity values between $47-93 \%$. Gamma-ray irradiation provides an increase in genetic diversity by $7 \%$. Based on the dendrogram it can be observed that the sample is divided into two groups, namely group A which consisted of plants at doses of $20 \mathrm{~Gy}, 30 \mathrm{~Gy}$, control (0 Gy) and group B consisting of plants at a dose of $10 \mathrm{~Gy}$. The closest kinship relationship occurs between plants at doses of 20 Gy and $30 \mathrm{~Gy}$ with a value of $0.93(93 \%)$. The plant groups of $20 \mathrm{~Gy}$ and $30 \mathrm{~Gy}$ doses, then have a coefficient of $63 \%$ with control plants. The $10 \mathrm{~Gy}$ dose has the most distant relationship compared to the other doses, namely the diversity coefficient of $0.47(47 \%)$. This shows that plants at a dose of $10 \mathrm{~Gy}$ have a banding pattern that is very different from other doses. Distant kinship at a $10 \mathrm{~Gy}$ radiation dose means that the radiation-exposed affects most genotypes in the plant due to changes in somatic cells.

\section{Discussion \\ Effect of irradiation on plant morphology}

Gamma irradiation is physical mutagens that have been reported by many researchers to induce mutations in plants. Radiation exposure can interact with cellular molecules, especially water to produce free radicals (Harten 1998; Fauza et al. 2005; Abdul et al. 2010; Dehgahi and Joniyasa 2017; Kemal et al. 2018). According to Taheri et al. (2013), free radicals can combine to form toxic substances such as hydrogen peroxide $\left(\mathrm{H}_{2} \mathrm{O}_{2}\right)$ which will cause damage to the cells. This is very important, especially in vegetative cells, because the cytoplasmic component is $80 \%$ of water (Kovac and Keresztes 2002). The damage that occurs in cells directly affects the morphology, biochemistry, and physiology of plants. Generally, the damage is highly dependent on the sensitivity of cells or tissues in plants.

In this study, gamma-ray irradiation at various doses significantly affects the growth of ambon kuning, especially the quantitative characteristics of stem diameter and leaf length). However, the effect that occurs is not proportional to the change in dose given. Plant height, leaf width and number of leaves do not show significant difference. Although it does not show significant difference between the control plant and the plants produced by irradiation, visually, the plants with the highest dose treatment show slower growth. Gamma-ray radiation at high doses has been reported to damage cellular components of macromolecules such as cell walls, membranes, and DNA (Wi et al. 2007).

In general, gamma ray irradiation at doses of $10 \mathrm{~Gy}$ and 20 Gy shows good growth in all parameters observed when compared with the control and the dose of $30 \mathrm{~Gy}$. The results of this study are consistent with the research conducted by Abdul et al. (2010) and Abdulhafiz et al. (2018), reporting an increase in horn banana plant growth at irradiation doses of $10 \mathrm{~Gy}$ and $20 \mathrm{~Gy}$. As reported by 
Janick (2008), an interesting phenomenon of growth stimulation can be found that plants that are given irradiation treatment show higher survival rates and better growth than untreated plants. Increased plant growth from irradiation results also occurred in the study of Suwarno et al. (2013) in which they found that radiation doses of 10 Gy and 20 Gy were optimal doses to stimulate orchid growth in all parameters of observation.

Gamma-ray radiation at the highest dose (30 Gy) shows a reduction in all growth parameters. This result is the same as the research conducted by Dewi and Dwimahyani (2013) which states that giving radiation doses of more than $20 \mathrm{~Gy}$ to hibiscus plants causes growth to be slow and can even cause death. Hasbullah et al. (2012) in their study reported that an increase in the dose of gamma irradiation can suppress plant cell activity and influence the morphological characteristics of plants as a result of chromosome aberrations in addition to genetic mutations. Afrasiab and Iqbal (2010) reported that higher doses of gamma radiation reduce the amount of endogenous growth regulators like cytokines. Although there is a reduction in growth in quantitative morphological properties, there is no significant reduction. Radiation of $10 \mathrm{~Gy}$ and $20 \mathrm{~Gy}$ in this study can be used as alternatives for plant breeding because it shows better survival and growth.

\section{Analysis of ISSR molecular markers}

Detection of genetic diversity using molecular markers of ISSR has been carried out in several previous studies (Wang et al., 2012; Patel et al., 2015; Taheri et al., 2013; Wang et al., 2017). Single nucleotide polymorphisms are the genetic markers of choice in various genetic, ecological and evolutionary studies (Tang et al. 2016). In this study, the level of polymorphism of pisang ambon DNA bands obtained by gamma irradiation is quite high, namely, at $90 \%$. From the 9 DNA bands produced by two ISSR primers, only 1 monomorphic band is observed while 8 others are polymorphic bands. The polymorphism resulted from the ISSR amplification comes from variations in DNA sequences at the primer attachment site. According to Reddy et al. (2002), the polymorphism may be due to mutation at priming sites and/or insertion/deletion event within the SSR region; and the extent of polymorphism also varies with the nature and the sequence repeat of the primer used.

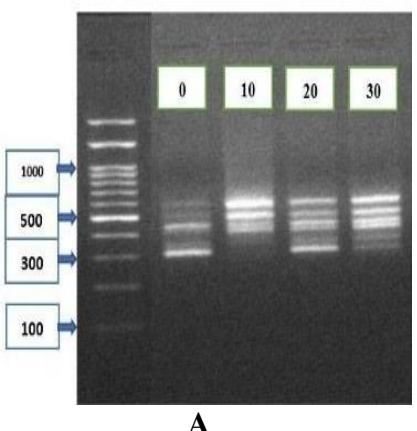

A

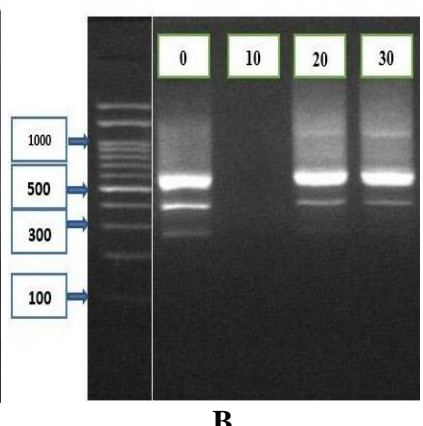

B
Figure 2. Amplification of the pisang ambon DNA pattern using ISSR 846 (A) and ISSR 855 primer (B)
From 6 selected ISSR primers, 4 primers have not been able to amplify properly because there is no match between the complement of pisang ambon DNA and the primary sequence used. This research is the same as the research conducted by Carsono et al. (2014) which shows that from 10 molecular SSR markers used for polymorphic identification of rice plants, only 6 primers are able to produce polymorphisms above $50 \%$, while 4 other primers do not meet the requirements because they do not produce polymorphism above $50 \%$ and some of them cannot be properly amplified. The same results also occur in the study of Lal et al. (2012) in the maximum species. From the 6 ISSR primers, 21 RAPD primers and 6 SSR primers only produced 3 ISSR primers, 11 RAPD primers, and 2 SSR primers which give satisfactory amplification results. According to Ye et al. (2005), in a successful ISSR analysis, the SSRs (inversely oriented) pairs must be within an adjacent distance on the same chromosome, which can be amplified by the PCR reaction to produce a band that can be absorbed by agarose gel or polyacrylamide. SSR locus in the genome that is not detected by ISSR analysis because the distance between two SSR motifs with opposite orientation is far apart or even though the motif is clustered at a distance that can be amplified by PCR detection, but SSR motifs are not oriented as required in PCR amplification.

The amplified DNA bands ranged from 275-1250 bp. Total DNA is detected in each primer depends on the base sequence of the primer and the presence or absence of variation in certain genotypes (Upadhyay et al. 2004). The ISSR primers used in this study is included in microsatellite primers, where the primer is designed from the microsatellite region which is a repetitive sequence. According to Udupa and Baun (2001), one of the important characteristics of repetitive sequences is the tendency for mutations that are higher than others (RAPD, AFLP, long primer-RAPD) and usually cause changes in their length arrangement. Microsatellites have spontaneous instability that is based on their vulnerability compared to other regions or the imbalance of the process of replication or recombination that is not the same and the high average of the two processes makes this locus brittle against radiation induction (Bridges, 2001). In general, the produced DNA bands have different thicknesses. DNA bands at base pairs 560 bp ISSR primary 855 control treatment, 20 Gy treatment and 30 Gy treatment appear thicker than the others. This is due to the presence of more recognizable segments of DNA in these base pairs so that they appear thicker (Poerba and Martanti, 2008).

The diversity dendrogram based on the ISSR marker shows that there is no specific pattern between the control and the plants produced by irradiation. Plants in the treatment of $20 \mathrm{~Gy}$ and $30 \mathrm{~Gy}$ have genetic similarity distance that is quite close to the control plants, while the plant of $10 \mathrm{~Gy}$ treatments is at the farthest distance compared to controls and other treatments (Figure 2). In general, the success of mutation induction is very dependent on plant material receiving mutagen treatment (Harten 1998). Besides plant material, primary selection is 
also very important. Wang et al. (2017) in his research on the Sophora davidii plant stated that the induction of gamma radiation was able to produce genetic diversity between $75-86 \%$ based on the ISSR marker. Another study conducted by Taheri et al. (2013) on Curcuma alismatifolia plants based on ISSR analysis results of gamma-ray irradiation obtained diversity between $27-100 \%$. In this study, the genetic diversity that occurred ranged from 47 93\%, whereas the increase was not too large at $7 \%$.

In conclusion, plants at irradiation doses of $10 \mathrm{~Gy}$ and 20 Gy experience increased growth in all morphological parameters that have been analyzed. The genetic diversity of pisang ambon from gamma-ray irradiation by molecular markers of ISSR increases by $7 \%$. The 10 Gy dose has a fairly high diversity from the other doses.

\section{REFERENCES}

Abdul M, Khan AUR, Habib A, Zahir M. 2010. Gamma irradiation effects on some growth parameters of Lepidium sativum L. J Agri Bio Sci 5 (1): 39-42.

Abdulhafiz F, Kayat F, Zakaria S. 2018. Effect of gamma irradiation on the morphological and physiological variation from In vitro individual shoot of banana cv. Tanduk (Musa spp.) J Plant Biotechnol 45 (2): 140-145.

Afrasiab H, Iqbal J. 2010. In vitro techniques and mutagenesis for the genetic improvement of potato cvs. Desiree and diamant. Pakistan J Bot 42 (3): 1629-1637.

Bakry F, Reberdiere NP, Pichot S, Jenny C. 2006. In liquid medium colchicine treatment induces non-chimerical doubled-diploids in a wide range of mono and interspecific diploid banana clones. Fruits 62 (1): $3-12$.

Bridges BA. 2001. Radiation and germline mutation at repeat sequence: are we in the middle of paradigm shift. Rad Res 156: 631-641.

Carsono N, Lukman PN, Damayanti F, Susanto U, Sari S. 2014 Identifikasi polimorfis marka-marka molekuler yang diduga berkaitan dengan karakter daya hasil tinggi pada 30 genotip padi. Chimica et Natura Acta 2 (1): 66-71.

Crouch JH, Vuylsteke D, Ortiz R. 1998. Perspectives on the application of biotechnology to assist the genetic enhancement of plantain and banana (Musa spp.). Intl Inst Trop Agric 1 (1): 717-3458.

Dehgahi R, Joniyasa A. 2017. Gamma irradiation induced variation in Dendrobium Sonia-28 orchid protocorm-like bodies (PLBs). Fungal Genom Biol 7 (2): 1-11.

Dewi AK, Dwimahyani I. 2013. Pengaruh radiasi gamma terhadap perubahan morfologi pertumbuhan stek tanaman kembang sepatu (Hibiscus rosa-sinensis). Beta Gamma 4 (2): 89-102.

Dwimahyani I, Widiarsih S. 2010. The effects of gamma irradiation on the growth and propagation of in vitro Chrysanthemum shoot explants (cv. Yellow Puma). Atom Indonesia 36 (2): 45-49.

Fauza H, Karmana MH, Rostini N, Mariska I. 2005. Pertumbuhan dan variabilitas fenotipik manggis hasil iradiasi sinar gamma. Zuriat 16 (2): 133-144. [Indonesian]

Frison EA, Escalante JV, S Sharrock. 2004. The Global Musa Genomic Consortium: a Boost for Banana Improvement. Science Publishers, Enfield, USA.

Gupta S, Pandey-Rai S, Srivastava S, Naithani SC, Prasad M, Kumar S. 2007. Construction of genetic linkage map of the medicinal and ornamental plant Catharanthus roseus. J Genet 86: 259-268.

Harten V. 1998. Mutation Breeding Theory and Practical Application. Press Syndicate of the University of Cambridge, UK.

Hasbullah NA, Taha RM, Saleh A, Noraini M. 2012. Irradiation effect on in vitro organogenesis, callus growth and plantlet development of Gerbera jamesonii. Horticultura Brasileira 30 (2): 252-257.

Herison C, Rustikawati HS, Surjono SI, Aisyah. 2008. Induksi mutasi melalui sinar gamma terhadap benih untuk meningkatkan keragaman populasi dasar jagung (Zea mays L.). Akta Agrosia 11: 57-62. [Indonesian]

Janick J. 2008. Plant Breeding Reviews. Avi Publisher Company, London.
Javed MA, Chai M, Othman R. 2004. Study of resistance of Musa acuminata to Fusarium oxysporum using RAPD markers. Biologia Plantarum 48 (1): 93-99.

Kemal FA, Kayat F, Zakaria S. 2018. Effect of gamma irradiation on the morphological and physiological variation from in vitro individual shoot of banana cv. Tanduk (Musa spp.). J Plant Biotechnol 45 (2): 140-145.

Kovacs E, Keresztes A. 2002. Effect of gamma and UV-B/C radiation on plant cells. Micron 33 (2): 199-210.

Kumar S, Prasad KV, Choudhary ML. 2006. Detection of genetic variability among Chrysanthemum radio mutants using RAPD markers. Curr Sci Assoc 90 (8): 1108-1113.

Lal S, Mistry K, Thaker R, Shah S, Vaidya P. 2012. Genetic diversity assessment in six medicinally important species of Ocimum from central Gujarat (India) utilizing RAPD, ISSR and SSR markers. Intl J Adv Biol Biomed Res 2 (2): 279-288.

Manimekalai R, Nagarajan P, Bharathi M, Naresh KS. 2003. DNA polymorphism among coconut (Cocos nucifera 1.) cultivars and reciprocal cross derivatives differing in drought tolerance. J Patio Crops 32 : 117-122.

Megia R. 2005. Musa as a genomics model. Hayati J Biosci 12 (4): 167170. [Indonesian]

Ng WL, Tan SG. 2015. Inter-simple sequence repeats (ISSR) markers. ASM Sci J 9 (1): 30-39.

Orbovic V, Calovic M, Viloria Z, Nielsen B, Grimitter F, Castle W, Grosser J. 2008. Analysis of genetic variability in various tissue culture derived lemon plant populations using RAPD and flow cytometry. Euphytica 161 (3): 329-335.

Patel HK, Fougat RS, Kumar S, Mistry JG, Kumar M. 2015. Detection of genetic variation in Ocimum species using RAPD and ISSR markers. Biotech 5 (5): 697-707.

Penna S, Vitthal SB, Yadav PV. 2012. In vitro mutagenesis and selection in plant tissue cultures and their prospects for crop improvement. Global Sci Books 6 (1): 6-14.

Poerba YS, Martanti D. 2008. Genetic variability of Amorphophallus muelleri Blume in Java based on Random Amplified Polymorphic DNA. Biodiversitas 9 (4): 245-249.

Prahardini PER, Krismawati A, Fatimah S. 2011. Institutional development potential banana seedling of banana center in three districts in East Java. In: Proceeding International Seminar on Natural Resources, Climate Change, and Food Security Developing Countries. Faculty of Agriculture, University of Pembangunan Nasional Veteran, 27-28 June. Surabaya, East Java.

Qamar M, Qureshi ST, Khan IA, Memon SA, Bano Z, Solangi SK. 2016. Influence gamma radiation on the physicochemical properties of in vitro triploid and tetraploid banana species. Pakistan J Biotechnol 13 (4): 237-244.

Reddy MP, Sarla N, Siddiq EA. 2002. Inter-simple sequence repeat (ISSR) polymorphism and its application in plant breeding. Euphytica 128 (1): 9-17.

Roux NS, Toloza A, Dolezel J, Panis B. 2004. Usefulness of embryogenic cell suspension cultures for the induction and selection of mutants in Musa spp. Science Publisher, USA.

Sari WP, Damanhuri, Respatijarti. 2014. Variability and heritability value of 10 genotypes of chilli (Capsicum annuum L.). Jurnal Produksi Tanaman 2 (4): 301-307. [Indonesian]

Suwarno A, Habibah NA, Herlina L. 2013. Respon pertumbuhan planlet anggrek Phalaenopsis amabilis L. var. Jawa Candiorchid akibat radiasi sinar gamma. Unes J Life Sci 2 (2): 78-84. [Indonesian]

Taheri S, Abdullah TL, Abdullah NAP. 2013. Use of inter simple sequence repeats assay for detection of DNA polymorphism induced by gamma rays in Curcuma alismatifolia. HortScience 48 (11): 13461351 .

Tang W, Wu T, Ye J, Sun J, Jiang Y, Yu J, Tang J, Chen G, Wang C, Wan J. 2016. SNP-based analysis of genetic diversity reveals important alleles associated with seed size in rice. BMC Plant Biol 16: 93. DOI: 10.1186/s12870-016-0779-3.

Tantasawat P, Trongchuen J, Prajongjai T, Seehalak W, Jittayasothorn Y. 2010. Variety identification and comparative analysis of genetic diversity in yardlong bean (Vigna unguiculata spp. sesquipedalis) using morphological characters, SSR and ISSR analysis. Scientia Horticulturae 124 (2): 204-216.

Udupa S, Baum M. 2001. High mutation rate and mutational bias at (TAA) microsatellite loci in Chickpea (Cicer arietinum L.). Mol Genet Genom 265: 1097-1103. 
Upadhyay A, Jayadev K, Manimekalai R, Parthasarathy VA. 2004 Genetic relationship and diversity in Indian coconut accessions based on RAPD markers. Scientia Horticulturae 99 (3): 353-362.

Wang A, Yu Z, Ding Y. 2009. Genetic diversity analysis of wild close relatives of barley from Tibet and the middle east by ISSR and SSR markers. Comptes Rendus Biologies 332 (4): 393-403.

Wang P, Zhang Y, Zhao L, Mo B, Luo T. 2017. Effect of gamma rays on Sophora davidii and detection of DNA polymorphism through ISSR marker. BioMed Res Intl 2017: 8576404. DOI: $10.1155 / 2017 / 8576404$

Wang X, Yang R, Feng S, Hou X, Zhang Y, Li Y, Ren Y. 2012. Genetic variation in Rheum palmatum and Rheum tanguticum (Polygonaceae), two medicinally and endemic species in China using ISSR markers. PLoS One 7(12): e51667. DOI: 10.1371/journal.pone.0051667.

Wi SG, Chung BY, Kim JS, Kim JH, Baek MH, Lee JW, Kim YS. 2007. Effects of gamma irradiation on morphological changes and biological responses in plants. Micron 38 (6): 553-564.

Widiastuti A, Sobir, Suhartanto MR. 2013. Genetic variability analysis of mangosteen (Garcinia mangostana) irradiated by gamma ray based on ISSR marker. Bioteknologi 10 (1): 15-22. [Indonesian]

Ye C, Yu Z, Kong F, Wu S, Wang B. 2005. R-ISSR as a new tool for genomic fingerprinting, mapping, and gene tagging. Plant Mol Biol Rep 23 (2): 167-177. 